\title{
Living on the edge: studies on ecology of plant species and populations at the limits of their geographic range. Tribute to Professor Janusz B. Faliński (1934-2004)
}

\author{
Bożenna Czarnecka
}

Department of Ecology, Faculty of Biology and Biotechnology, Maria Curie-Skłodowska University, Akademicka 19, 20-033 Lublin, Poland e-mail: bozenna.czarnecka@poczta.umcs.lublin.pl

\begin{abstract}
Abies alba and Senecio rivularis - two of 44 mountain species reported from the Roztocze Highlands, SE Poland were objects of the study. Both species reach the north-eastern limits of their occurrence in this region. In case of Abies alba, the extent of its habitat niche and possibility of adaptation to alternative niches at the range limits were investigated in two areas of the Roztocze Highlands - the Roztocze National Park (RNP) and gorge sections of four river valleys (RV) of a mountainous character. In both landscapes, fir prefers mineral soils that are too leachy for deciduous species and even for spruce. In the RV sites, fir seems to have a much broader ecological scale and often colonizes organic soils with wet mixed coniferous forests with spruce, ash-alder, and bog alder forests.

The studies on Senecio rivularis are an example of long-term ecological studies at the population level, conducted in the RNP since 1987, e.g., in terms of changes in the size structure of individuals compared to the changes in the surface area covered by this population. A nearly 3 -fold increase in the area inhabited by the population was accompanied by changes in the spatial organisation of the population and individual size structure dynamics, which reflects the intensification of intra- and interspecific competition, and indicates condition changes in the population area.
\end{abstract}

Key words: edaphic conditions, habitat niche, individual size structure, marginal population, mountain species, vegetation landscapes

\section{Introduction}

The Roztocze Highlands, SE Poland, is a metaCarpathian arch of uplands extending from Kraśnik to Lviv with a length of $185 \mathrm{~km}$, including $110 \mathrm{~km}$ in Poland, and a width from 15 to $28 \mathrm{~km}$. The area constitutes a structural unit consisting of tectonic blocks limited by tectonic escarpments and grabens in the form of plateaus and hummocks with absolute height from NW to SE between 290 and $400 \mathrm{~m}$ a.s.l. The north-eastern border of the region is less evident, whereas in the south-west, the outer escarpment declines towards the Sandomierz Basin (Fig. 1). The escarpment zone of the region is one of the longest tectonic faults in Poland. The core of the Roztocze Highlands is formed by Cretaceous rocks (opokas and gaizes, and less frequently marly opokas and marls), which are covered by Neogene formations in the southern part of the escarpment (Buraczyński 2002).
The location, climate, geomorphological and hydrogeological, and consequently edaphic conditions determine the high diversity of the region's flora. One of the characteristic features of the Roztocze Highlands is a considerable participation of vascular plants from the Holarctic element, whose centre of occurrence is connected with mountains, and which reach limits of their massive occurrence there. The presence of mountain flora in the Roztocze region may be explained not only by the considerable elevation of this region in respect to the surrounding areas, or the current habitat and climate conditions, but also by the closeness to the refugium and suitable conditions that facilitate migration of mountain plants from the East Carpathians (Szafer 1930; Pawłowska 1972). During the last 50 years, 44 taxa, i.e. $37.3 \%$ of all mountain species of the Polish flora (Zajac 1996), have been reported from the region (Czarnecka 2010). Two of them, which extend to the north-eastern border of their range in Poland, i.e. silver fir Abies alba 


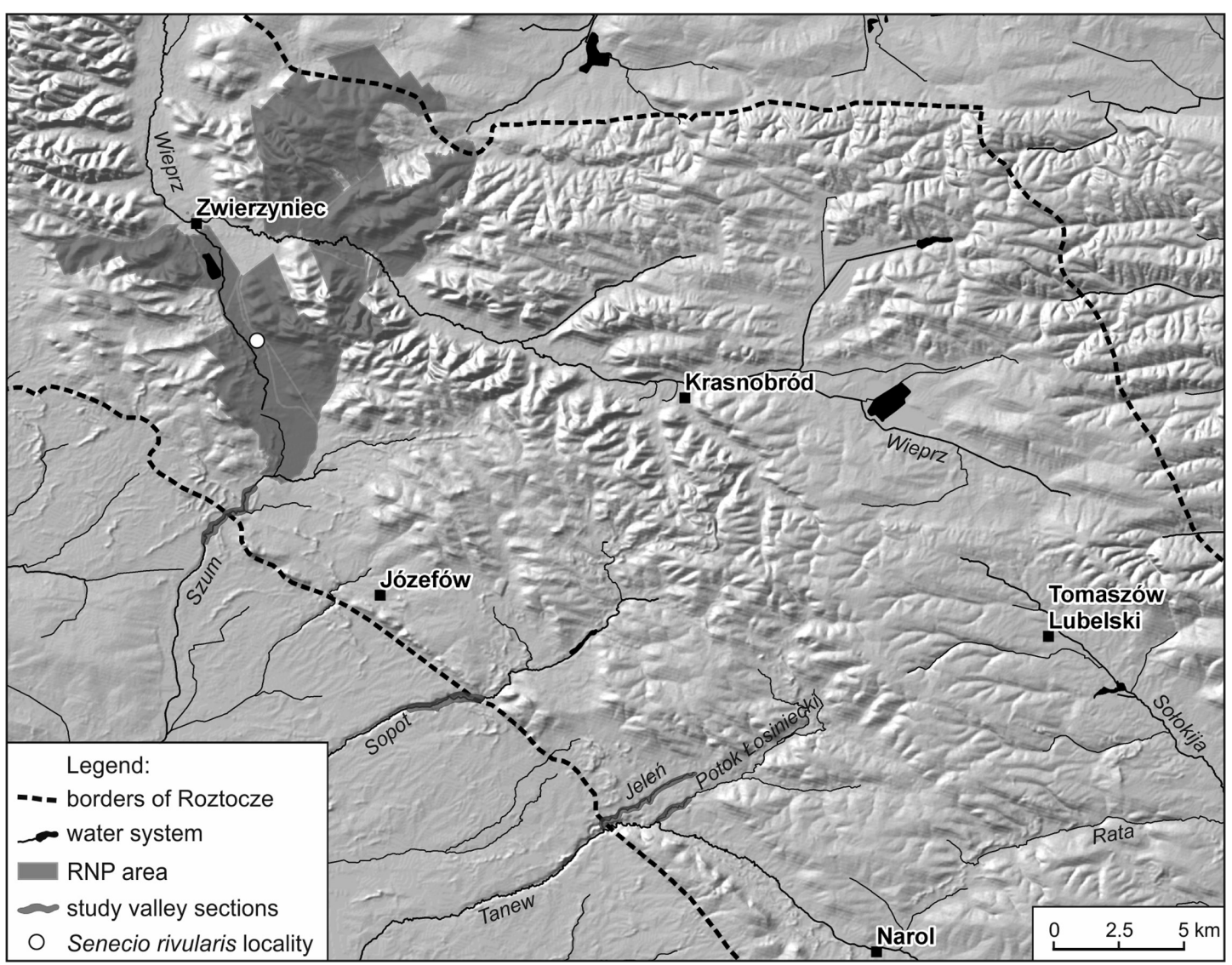

Fig. 1. Localization of the Roztocze National Park (RNP) and right-hand tributaries of the Tanew river crossing south-western escarpment zone of the Roztocze Highlands (elaborated by Ł. Chabudziński). Vertical exaggeration $=5$

Mill. and ragwort Senecio rivularis (Waldst. \& Kit.) DC., are the objects of detailed studies.

A. alba, belonging to the Alpine-Central European sub-element of the Polish flora, is a species of broad ecological amplitude. In the Carpathians and adjacent areas, it finds optimal thermal conditions at a mean annual temperature ranging from 4 to $8^{\circ} \mathrm{C}$. Fir occurrence is strongly connected with the precipitation amount and its distribution throughout the year; the northern border of the species is limited by the isohyet of 600 $\mathrm{mm}$ per year. Forests with fir can grow on different relief forms: plains and plateaus, convex forms and depressions. Silver fir tolerates a wide range of edaphic conditions in respect of soil moisture, acidity, organic matter content, nutrient availability, and granulometric composition, and grows on different soil types. In mountains, silver fir appears in beech forests (Dentario glandulosae-Fagetum, Dentario enneaphylli-Fagetum and Luzulo luzuloidis-Fagetum) and spruce-fir forests (Abieti-Piceetum montanum, Galio-Piceetum) of the lower forest belt, while in highlands it occurs in the Carpathian beechwood and, especially, in upland mixed fir forests (Abietetum polonicum; Matuszkiewicz J. 1977, 2001; Jaworski \& Zarzycki 1983; Wojterski 1983; Zarzycki et al. 2002). The latter one is an endemic com- munity of the southern Poland uplands included in the list of EU priority habitats, known as the Holly Cross fir forest - code 91P0 (European Commission 2007).

The aim of the study on A. alba was to answer the following questions: How wide is its habitat niche at the limit range? Does the species expand its optimal niche in upland regions (mixed fir forests; acid brown and podzol soils) and adapts to alternative niches, thereby contributing to greater diversity in the occupied habitats?

The other species, S. rivularis, the Alpine-Carpathian sub-element of the Polish flora, occurs mainly in the mountains and highlands; its most numerous locations are found in the Sudety Mountains, the West Carpathians, the Bieszczady Mountains, the Małopolska Highland, and the Silesian Lowland (Zając 1996; Zając \& Zając 2001). Further north and east, its localities are scattered, especially in the Vistula and Bug interfluve, where the species is recognized as critically endangered (Kucharczyk 2000). S. rivularis prefers full light and seasonal or transitory shading. It primarily appears in damp places, e.g. in tall herb communities, riverside ash-alder forests and bog alder forests, wet meadows, and mesotrophic sedge mires. The species inhabits moist, rather peat-rich, moderately or slightly acid soils 
with a considerable proportion of mineral elements (Meusel \& Jäger 1992; Zarzycki et al. 2002).

The present study on S. rivularis aimed to find out, among others, whether the size of individuals reflected in their vegetative and generative traits is constant or variable over time, and how it accompanied the temporal changes in the area inhabited by the population.

\section{Material and methods}

\subsection{Studies on Abies alba}

The studies on Abies alba involved analyses of habitat conditions occurring in two areas in the central part of the Roztocze Highlands: the Roztocze National Park (RPN sites) and gorge sections (3-4 km long each) of four river valleys of the right-hand tributaries of the Tanew river, crossing the escarpment zone of the region: the Szum, Sopot, Jeleń, and Łosiniecki Stream, which in the central part of the escarpment region form ravines of a mountainous character (Fig. 1). Due to the similarities in their character, namely the topography, geological formation of the valleys, and toposequence of forest communities, the analysed river gorge sections were treated as one object, which is hereinafter referred to as 'river valleys' ( $\mathrm{RV}$ sites).

The analysis was based on 222 phytosociological relevés taken in forest communities with a silver fir component at the end of the 1980s and 1990s (Izdebski et al. 1992; Czarnecka \& Janiec 2002; B. Czarnecka, unpubl. data): 123 from the RNP sites and 99 from the RV sites. They were analysed in terms of: (1) silver fir abundance, using an 11-degree scale $(+-$ sporadic species, cover $<5 \%, 1$ - cover lower than $10 \%, 2$ - cover between 10 and $20 \%, \ldots 10$ - cover between 90 and $100 \%$ ) in the tree layer and in the understorey; (2) the main character of the habitat in each site: topography (plain and plateau sites - less than $5^{\circ}$ and slopes - steeper than $5^{\circ}$ ) and character of soils (mineral or organic, i.e. $<20 \%$ and $>20 \%$ of organic matter content, respectively). The type of plant community was determined in each case. Results of soil analyses were available for one fourth of the analysed forest patches (39 and 33 soil pits in the RNP and RV sites, respectively). Using the commonly accepted methods (Dobrzański et al. 1992; Sapek \& Sapek 1992), the following soil properties were determined: $\mathrm{pH}$ in dist. $\mathrm{H}_{2} \mathrm{O}$, content of organic carbon/ organic matter, and $\mathrm{Ca}^{2+}$ and $\mathrm{Fe}^{3+}$ ions.

The U Mann-Whitney and Kruskall-Wallis tests were used and calculation of the Spearman rank correlation index was conducted with the help of Statistica. $\mathrm{Pl}$ software to check the significance of differences in the cover of fir in the different habitats.

The nomenclature of species is given after Mirek et al. (2002), of plant communities follows J. M. Matuszkiewicz (2001) and W. Matuszkiewicz (2008), and orders/types of soils follow the Polish Pedological Society classification (Trzciński 1989).

\subsection{Studies on Senecio rivularis}

Since 1987, the marginal population of Senecio rivularis located in the RNP (Fig. 1) has been an object of long-term studies in the sense expressed by Faliński (2001). It inhabits a forest community of a transient character between bog alder forest and ash-alder forest, with introduced Scotch pine Pinus sylvestris L., which is an example of synanthropisation of the community, i.e. pinetisation (Czarnecka 1995). Out of the many aspects of the studies, the following two were chosen for the purpose of the present paper: changes in the surface area covered by the population and dynamics of the size structure of individuals in the population.

In 1987, the whole population area was divided into permanent $5 \times 5 \mathrm{~m}\left(25 \mathrm{~m}^{2}\right)$ plots. In the high vegetation seasons in 1987, 1991 and 1997, 1:50-scaled plans of the location of all ragwort individuals and aggregations were made (Czarnecka 1995, 2008, 2011). In 2002 and 2012, the plan was completed with the localities of patches that had developed on the periphery of the area. Next, using the ArcGIS software, the surface area covered by the population (defined by lines connecting the extreme sites of $S$. rivularis clusters), the perimeter of the population area and the shoreline development factor K (Bajkiewicz-Grabowska \& Mikulski 1999) were calculated in the successive research seasons.

Changes in the size structure were determined for plants in two life stages, namely, mature vegetative and generative (i.e. flowering) individuals. Assessment of the size structure of vegetative individuals was made four times $(1987,1991,1997,2012)$ in terms of the number of leaves per rosette, length of the longest leaf, and width of the longest leaf. The size structure of flowering individuals was assessed six times $(1987,1991$, $1997,2002,2007,2012$ ) in respect of the stem height, leaf rosette diameter (two transverse measurements), inflorescence diameter (two transverse measurements), and the number of flower heads per one umbel. Each time, 100 and 300 plants in the vegetative and generative stages, respectively, were chosen randomly in the population area and measured in situ, i.e. in the least destructive way for the fate of the future population.

The measurement results of the size structure of individuals were analysed statistically using a Microsoft Office Excel 2007 spreadsheet by calculating mean values $(\bar{x})$, standard errors (SE), standard deviations (SD) and coefficient of variation (CV). For each research season, in the absence of at least one parameter defined as a value describing a given trait of the generative individuals, the plants were excluded from the analysis; hence, the number of the analysed probes is sometimes lower than that of the measured individuals. The type 
of distribution of each data series was identified using the Shapiro-Wilk test. The significance of differences between the mean values in the different seasons was verified with the non-parametric Friedman test for repeatable measurements or the parametric Levene's test (Stanisz 1998; Łomnicki 2007).

\section{Results}

\subsection{Spatial arrangement of the Abies alba habitats}

Abies alba is a species present in a broad spectrum of plant communities both in the RNP and RV sites (Tables 1-2). The centre of silver fir occurrence in both areas are phytocoenoses of the upland mixed fir forest Abietetum polonicum of two sub-associations: a poorer sub-association, hereinafter referred to as 'typical' (A. p. typicum), and a richer one, named 'fertile' ( $A$. $p$. circaeetosum), where the mean cover of fir in the tree layer achieves the degree of 6 , and at some sites it is even 8 ; these communities were shown by $20.3 \%$ of all the analysed phytosociological relevés. In both study areas, there are also other mixed coniferous forests with A.alba (14.9\% in total): mainly, moist mixed forest with spruce Querco-Piceetum and rarely oak-pine forest Querco roboris-Pinetum, and pine forests (10.8\%): mainly,
Table 1. Percentage share of forest communities with the presence of Abies alba in the Roztocze Highlands (Roztocze National Park - RNP) and the river valleys sites (RV) elaborated on the basis of number of phytosociological relevés from each area

\begin{tabular}{lccr}
\hline Forest community & $\begin{array}{c}\text { Total } \\
\text { share }\end{array}$ & $\begin{array}{r}\text { RNP } \\
\text { sites }\end{array}$ & \multicolumn{1}{c}{$\begin{array}{c}\text { RV } \\
\text { sites }\end{array}$} \\
\hline \multicolumn{1}{c}{ With a similar share in both areas } \\
\hline Mixed fir forests & 20.3 & 8.1 & 12.2 \\
Other mixed forests & 14.9 & 7.7 & 7.2 \\
Pine forests & 10.8 & 5.0 & 5.8 \\
\hline
\end{tabular}

\begin{tabular}{lrrr}
\hline \multicolumn{4}{c}{ With a greater share in the RNP } \\
\hline Carpathian beechwood & 13.1 & 13.1 & 0.0 \\
Lime-hornbeam forest & 7.7 & 7.7 & 0.0 \\
Xero-thermophilous oak forest & 1.4 & 1.4 & 0.0 \\
Secondary pine communities & 13.1 & 10.4 & 2.7 \\
\hline \multicolumn{4}{c}{ With a greater share in river valleys } \\
\hline Ash-alder forest & 11.3 & 0.9 & 10.4 \\
Bog alder forest & 6.3 & 1.4 & 5.0 \\
Maple-lime forest & 1.4 & 0.0 & 1.4 \\
\hline
\end{tabular}

Leucobryo-Pinetum, but also Peucedano-Pinetum, Molinio-Pinetum and Vaccinio uliginosi-Pinetum. Silver fir is also a very important forest-forming species in the Carpathian beechwood Dentario glandulosaeFagetum and lime-hornbeam forest Tilio-Carpinetum

Table 2. Cover of Abies alba in different forest communities of the Roztocze Highlands

\begin{tabular}{lrrrrrrrrrrrc}
\hline Data & 1 & 2 & 3 & 4 & 5 & 6 & 7 & 8 & 9 & 10 & 11 & $P$ \\
\hline & & \multicolumn{10}{c}{ Tree layer } \\
Mean cover & 6.1 & 5.8 & 1.3 & 1.4 & 0.4 & 2 & 2.6 & 0.3 & 1.1 & 0.6 & 2.3 & $<0.0001$ \\
Min & 2 & 2 & 0 & 0 & 0 & 0 & 0.5 & 0 & 0 & 0 & 2 & - \\
Max & 8 & 8 & 4 & 4 & 3 & 5 & 8 & 0.5 & 3 & 2 & 3 & - \\
& & \multicolumn{1}{c}{ Understorey layer } & & & & & \\
Mean cover & 1.6 & 1.1 & 0.7 & 2.3 & 1.2 & 0.7 & 1 & 1.2 & 0.5 & 0.6 & 0.5 & $<0.0001$ \\
Min & 0 & 0.5 & 0 & 0.5 & 0 & 0 & 0 & 0.5 & 0 & 0 & 0.5 & - \\
Max & 5 & 2 & 2 & 4 & 4 & 3 & 3 & 2 & 2 & 2 & 0.5 & - \\
No. of sites & 34 & 11 & 31 & 14 & 24 & 29 & 17 & 3 & 25 & 14 & 3 & - \\
\hline
\end{tabular}

Explanations: differences were analyzed with the Kruskall-Wallis test; 1 - typical mixed fir forest, 2 - fertile mixed fir forest, 3 - other mixed forests, 4 secondary pine communities, 5 - pine forests, 6 - Carpathian beechwood, 7 - lime-hornbeam forest, 8 - xero-thermophilous oak forest, 9 -ash-alder forest, 10 - bog alder forest, 11 - maple-lime forest

Table 3. Correlation between the mean cover of Abies alba and topography

\begin{tabular}{lcccccccc}
\hline \multirow{3}{*}{ Data } & \multicolumn{3}{c}{ Tree layer } & \multicolumn{5}{c}{ Understorey layer } \\
\cline { 2 - 9 } & $\begin{array}{c}\text { Plains/ } \\
\text { plateaus }\end{array}$ & Slopes & $P$ & $\mathrm{R}$ & $\begin{array}{c}\text { Plains/ } \\
\text { plateaus }\end{array}$ & Slopes & $P$ & $\mathrm{R}$ \\
\hline All sites & 1.95 & 2.86 & $\mathrm{NS}$ & 0.13 & 1.01 & 1.03 & $\mathrm{NS}$ & 0.07 \\
& $\mathrm{n}=143$ & $\mathrm{n}=64$ & $\mathrm{NS}$ & $\mathrm{n}=143$ & $\mathrm{n}=64$ & & $\mathrm{NS}$ \\
RNP sites & 2.18 & 1.08 & $\mathrm{NS}$ & -0.18 & 1.23 & 0.65 & $\mathrm{NS}$ & -0.18 \\
& $\mathrm{n}=100$ & $\mathrm{n}=13$ & $\mathrm{NS}$ & $\mathrm{NS}$ & $\mathrm{n}=100$ & $\mathrm{n}=13$ & & $\mathrm{NS}$ \\
RV sites & 1.4 & 3.30 & & 0.33 & 0.52 & 1.13 & $<0.0001$ & 0.43 \\
& $\mathrm{n}=43$ & $\mathrm{n}=51$ & $<0.01$ & $P<0.01$ & $\mathrm{n}=43$ & $\mathrm{n}=51$ & & $P<0.0001$
\end{tabular}

Explanations: differences were analyzed with the U Mann-Whitney test, R - Spearman rank correlation index 


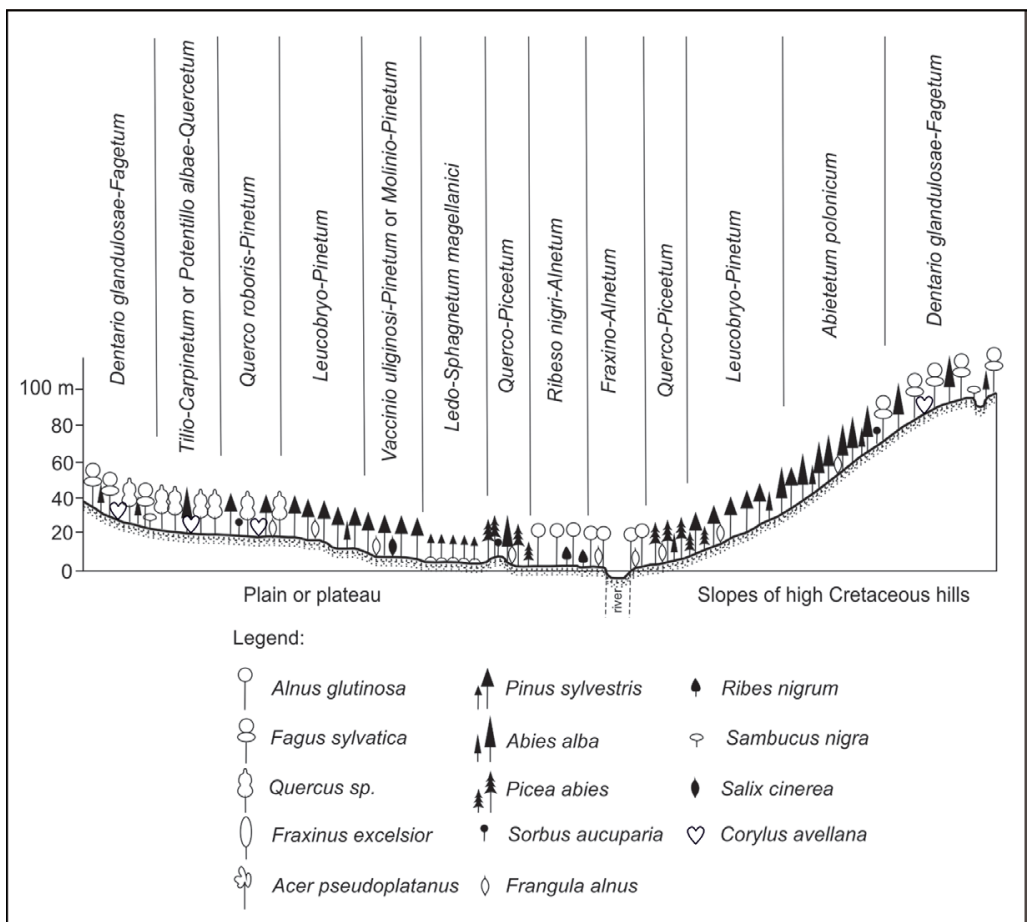

Fig. 2. Schematic draw of forest communities' sequence versus topography of the Roztocze Highlands (Izdebski et al. 1992, changed and supplemented)

in the RNP, i.e., in forest communities almost absent from the RV sites. A. alba was found to be an important admixture in ash-alder forests Fraxino-Alnetum and bog alder forests Ribeso nigri-Alnetum (rarely also Sphagno squarrosi-Alnetum) connected with the river valleys. Small patches of xero-thermophilous oak for- est Potentillo albae-Quercetum and maple-lime forest (Acer-Tilia community) are present in the RNP and RV sites, respectively.

The analysis of the topography and cover of $A$. alba showed differences between the spatial distribution of silver fir in both study areas (Table 3). In the RNP, i.e.

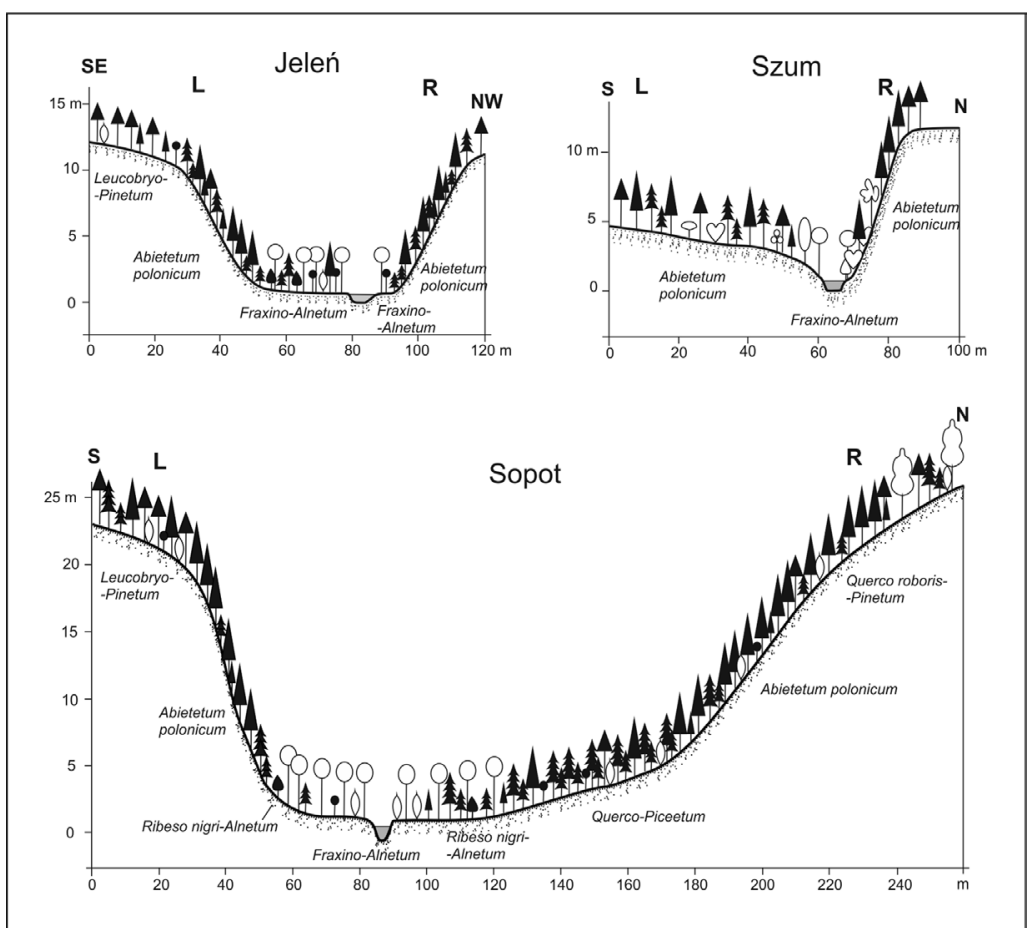

Fig. 3. Toposequence of forest communities in the river valleys (Czarnecka \& Janiec 2006, changed) Explanations: L, R - left and right hand river banks. Symbols of dominant tree and shrub species as in Fig. 2 


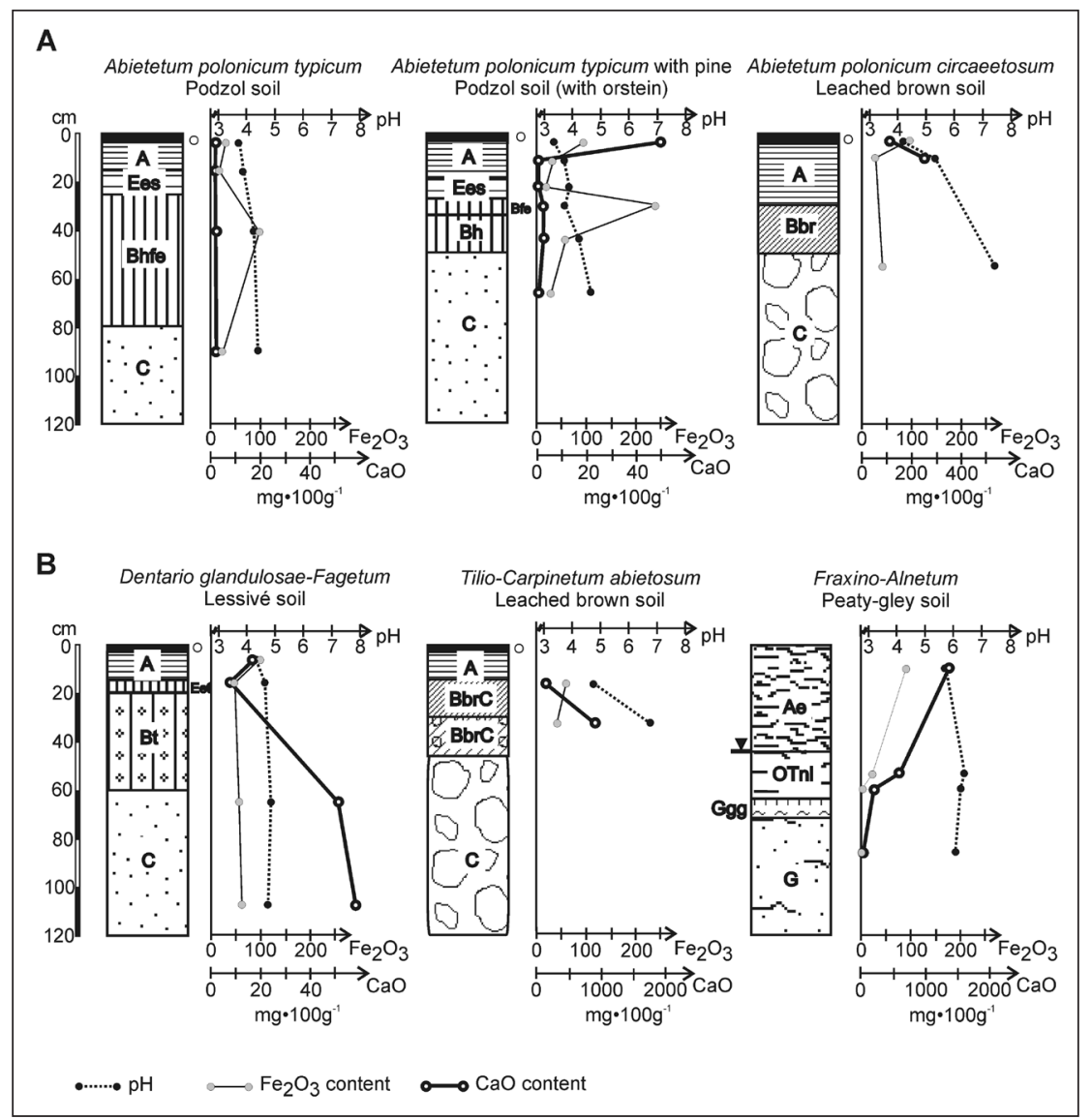

Fig. 4. Soil profiles under forest communities with Abies alba in the Roztocze National Park (Izdebski et al. 1992, changed and supplemented) Explanations: A - upland mixed fir forests, B - other communities. Soil types and symbols of horizons according to the Polish Pedological Society (Trzciński 1989)

in the landscape of Cretaceous and rarely Neogene hills, upland mixed fir forests and also other coniferous and mixed forests are present at plain and plateau sites. Slopes sites are insignificant there, while steep slopes are mainly overgrown with the Carpathian beechwood, which is totally absent from the RV sites. In the landscape of the river valleys, the steep slopes are the main sites of mixed fir forest occurrence and the plain habitats in close vicinity of river watercourses are overgrown with moist mixed coniferous forest with spruce and, first of all, with riverside ash-alder and bog alder forests (Figs. 2-3).

A majority of upland mixed fir forests occupy soils from authogenic and lithogenic (rarely) divisions

Table 4. Forest communities with Abies alba and soil types

\begin{tabular}{|c|c|c|c|c|c|c|c|c|c|c|}
\hline \multirow{2}{*}{$\begin{array}{l}\text { Soil division } \\
\text { Order/type }\end{array}$} & \multicolumn{10}{|c|}{ Forest community } \\
\hline & 1 & 2 & 3 & 4 & 5 & 6 & 7 & 8 & 9 & 10 \\
\hline \multicolumn{11}{|l|}{ Lithogenic soils } \\
\hline Rendzinas & & + & & & & & & + & ++ & \\
\hline \multicolumn{11}{|l|}{ Authogenic soils } \\
\hline Brown soils & + & ++ & & & & ++ & ++ & + & & \\
\hline Lessivés & & & & & & +++ & ++ & & & \\
\hline Podzols & +++ & & +++ & +++ & +++ & + & & & & \\
\hline Alluvial soils & & & + & & & & & & ++ & \\
\hline Semihydrogenic soils & & & + & & & & & & ++ & + \\
\hline Hydrogenic soils & & & ++ & & & & & & + & ++ \\
\hline
\end{tabular}

Explanations: +++- most important habitat; ++ - less important habitat; + - habitat of marginal importance; 1 - typical mixed fir forest, 2 - fertile mixed fir forest, 3 - other mixed forests, 4 - secondary pine communities, 5 - pine forests, 6 - Carpathian beechwood, 7 - lime-hornbeam forest, 8 - xero-thermophilous oak forest, 9 - ash-alder forest, 10 - bog alder forest 


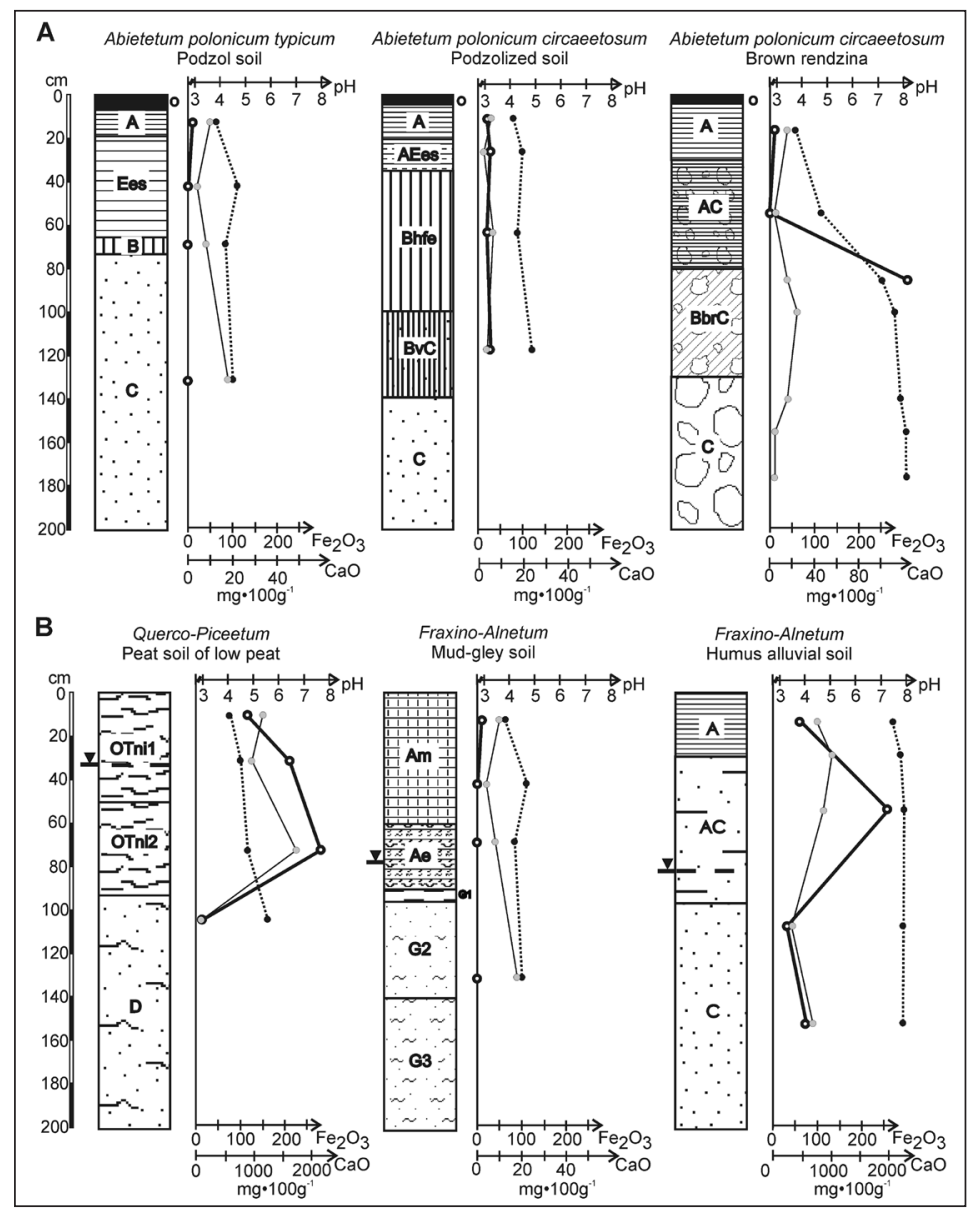

Fig. 5. Soil profiles under forest communities with Abies alba in the river valleys. Explanations as in Fig. 4

(Table 4). First of all, they represent proper podzols, both in the RNP and RV sites (Figs. 4A, 5A). These soils are habitats for phytocoenoses of the typical as well as fertile sub-association of Abietetum polonicum and secondary pine communities of the class VaccinioPiceetea at the former fir forest sites. When we consider other mixed and coniferous forests with the admixture of A. alba, the soil spectrum for the species is getting much wider, including some types of semihydrogenic, hydrogenic, and alluvial divisions, especially in the RV sites (Table 4, Fig. 5B).

As an admixture in tree stands and understorey of deciduous forests in the RNP sites, silver fir was found on different types of soils, most often on lessive and brown soils (proper, leached and acidic ones) - under phytocoenoses of the Carpathian beechwood and lime-hornbean forest, particularly representing the sub-association of Tilio-Carpinetum abietosum, specific for the RNP area (Fig. 4B). Semihydrogenic (gley, mud-gley, peat-mud, and peaty gley soils) and alluvial soils (proper, humus, and brown) are overgrown with ash-alder forests (Figs. 4B, 5B). On the flood-plain bench of the rivers Szum and Sopot, this type of deciduous forest was also found on brown and humus rendzinas. Bog alder forests with a small admixture of fir were found on hydrogenic (peat) soils of low fens.

Table 5. Correlation between the mean cover of Abies alba and soil group

\begin{tabular}{|c|c|c|c|c|c|c|c|c|}
\hline \multirow{2}{*}{ Data } & \multicolumn{4}{|c|}{ Tree layer } & \multicolumn{4}{|c|}{ Understorey layer } \\
\hline & Mineral & Organic & $P$ & $\mathrm{R}$ & Mineral & Organic & $P$ & $\mathrm{R}$ \\
\hline All sites & $\begin{array}{r}2.42 \\
\mathrm{n}=181\end{array}$ & $\begin{array}{r}0.86 \\
\mathrm{n}=26\end{array}$ & $<0.05$ & $\begin{array}{r}0.16 \\
P<0.05\end{array}$ & $\begin{array}{r}1.11 \\
\mathrm{n}=181\end{array}$ & $\begin{array}{r}0.38 \\
\mathrm{n}=26\end{array}$ & $<0.0001$ & $\begin{array}{r}0.33 \\
P<0.0001\end{array}$ \\
\hline RNP sites & $\begin{array}{r}2.14 \\
\mathrm{n}=107\end{array}$ & $\begin{array}{c}0.58 \\
n=6\end{array}$ & NS & $\begin{array}{l}0.1 \\
\text { NS }\end{array}$ & $\begin{array}{r}1.2 \\
\mathrm{n}=107\end{array}$ & $\begin{array}{l}0.58 \\
\mathrm{n}=6\end{array}$ & NS & $\begin{array}{r}0.14 \\
\text { NS }\end{array}$ \\
\hline RV sites & $\begin{array}{r}2.84 \\
\mathrm{n}=74\end{array}$ & $\begin{array}{r}0.95 \\
\mathrm{n}=20\end{array}$ & $<0.01$ & $\begin{array}{r}0.27 \\
P<0.01\end{array}$ & $\begin{array}{r}0.99 \\
\mathrm{n}=74\end{array}$ & $\begin{array}{r}0.32 \\
\mathrm{n}=20\end{array}$ & $<0.0001$ & $\begin{array}{r}0.43 \\
P<0.0001\end{array}$ \\
\hline
\end{tabular}

Explanations: differences were analyzed with the U Mann-Whitney test, $\mathrm{R}$ - Spearman rank correlation index 
As demonstrated by all the data and the data for the RV sites, $A$. alba shows significantly strong correlations with mineral soils. Organic soils are connected mainly with the river valleys while in the RNP, the share of these soils is insignificant (Table 5). Basic soil analysis ( $\mathrm{pH}$, $\mathrm{Fe}$ and $\mathrm{Ca}$ ions) proved a high flexibility of the species (Figs. 4-5). Silver fir prefers mineral soils both in and outside river valleys, but the soil characteristics vary very strongly. Mixed fir forests where fir is dominant grow on acidic soils, with $\mathrm{pH}$ ranging from 3.23 (a typical mixed fir forest in the RNP area) to 4.20 (a typical mixed fir forest in the Jelen river valley). However, even in the case of the mixed fir forest, the soil spectrum of this plant community is wider. It was also found on neutral soils $(\mathrm{pH}=7.15)$, but the share of fir was lower there. When other plant communities with an admixture of fir are taken into consideration, the flexibility of fir becomes even more evident. It is an admixture in pine forest ( $\mathrm{pH}=3.30$; the RNP site) and in ash-alder forest $(\mathrm{pH}=7.57$; the $\mathrm{RV}$ site $)$.

\subsection{Temporal arrangement of the Senecio rivularis population}

The area covered by the population of Senecio rivularis increased nearly 3 -fold from $2463 \mathrm{~m}^{2}$ in 1987 to $7209 \mathrm{~m}^{2}$ in 2012 (Fig. 6). The increase observed in the subsequent study periods was $36,21,27$, and $39 \%$ of the

Table 6. Spatial distribution of Senecio rivularis individuals (genets) in the $5 \times 5 \mathrm{~m}\left(25 \mathrm{~m}^{2}\right)$ plot in the years 1987-2007 (Czarnecka 2008, supplemented)

\begin{tabular}{cccccc}
\hline \multirow{2}{*}{ Year } & \multirow{2}{*}{$\begin{array}{c}\text { Total number } \\
\text { of genets }\end{array}$} & \multicolumn{3}{c}{ Genets per $\mathrm{m}^{2}$} & \multirow{2}{*}{$I^{*}$} \\
\cline { 3 - 5 } & mean $\pm \mathrm{SD}$ & $\min$ & $\max$ & \\
\hline 1987 & 357 & $14.3 \pm 1.6$ & 0 & 32 & 4.69 \\
1988 & 388 & $15.5 \pm 1.7$ & 0 & 32 & 4.56 \\
1989 & 375 & $15.0 \pm 1.6$ & 0 & 29 & 4.42 \\
1990 & 392 & $15.7 \pm 1.6$ & 0 & 29 & 4.29 \\
1991 & 422 & $16.9 \pm 1.8$ & 0 & 30 & 4.63 \\
1997 & 407 & $16.3 \pm 1.1$ & 0 & 31 & 2.03 \\
2007 & 224 & $9.0 \pm 8.3$ & 0 & 26 & 7.67 \\
\hline
\end{tabular}

Explanations: $I^{*}$ - Leksis' index (Steinhaus 1947), $I<1$ tendency to uniform distribution, $I=1$ random distribution, $I>1$ clumped distribution

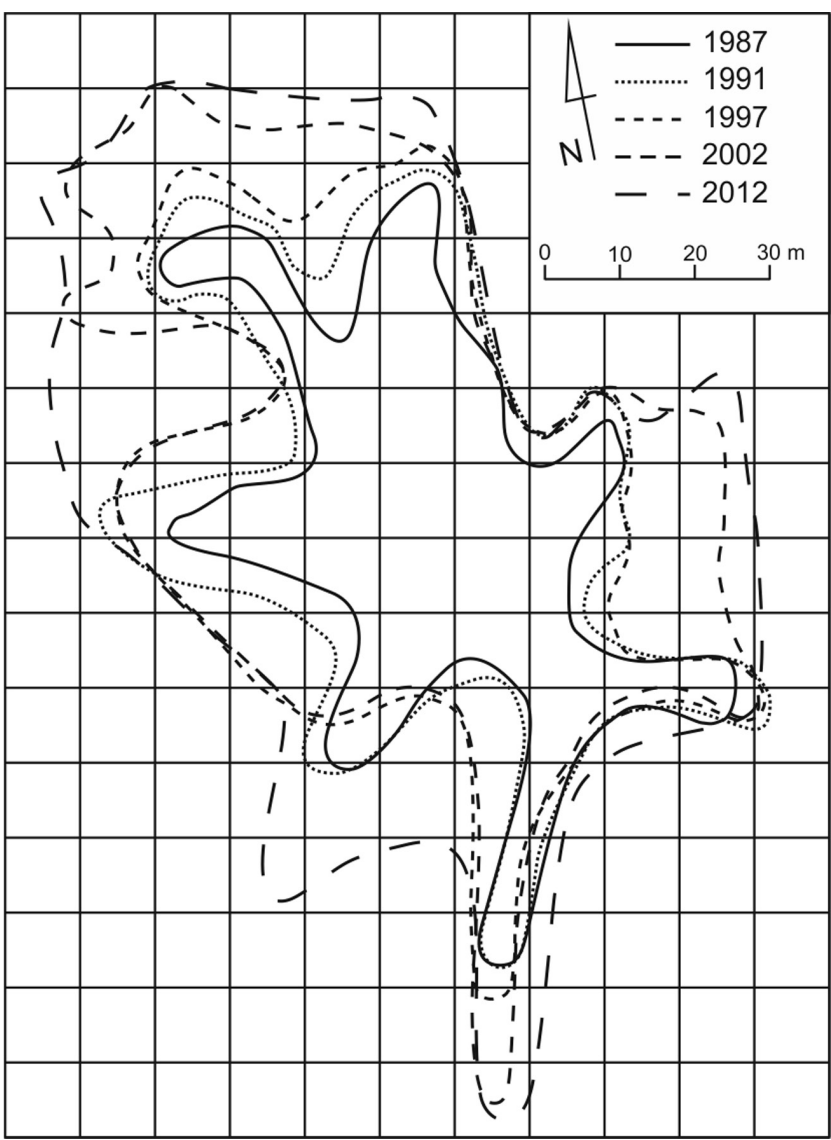

Fig. 6. Changes in the area occupied by the Senecio rivularis population in the Roztocze National Park in 1987-2012

value obtained in each preceding one. The area inhabited by the population was found to be more compact at each study series, which was indicated by the values of the shoreline development factor $\mathrm{K}(\mathrm{K}=1$ denotes a circular shape): $2.26,2.07,1.74,1.78$, and 1.47 .

The increase in the area inhabited by the population was accompanied by changes in the abundance and spatial organisation of the population and individual size structure dynamics. In the first study period (19871991), the whole population abundance increased 2.3fold - from 5567 to 12686 genets, and significantly exceeded the increase in the area covered by the population (1.36-fold). The mean density of individuals in the

Table 7. Changes in the features of vegetative Senecio rivularis individuals in 1987-2012

\begin{tabular}{|c|c|c|c|c|c|c|c|c|c|c|c|c|c|c|c|}
\hline \multirow[t]{2}{*}{ Year } & \multicolumn{5}{|c|}{ No. of leaves } & \multicolumn{5}{|c|}{ Length of the longest leaf [cm] } & \multicolumn{5}{|c|}{ Width of the longest leaf [cm] } \\
\hline & mean $\pm \mathrm{SD}$ & $\pm \mathrm{SE}$ & $\min$ & $\max$ & $\begin{array}{l}\mathrm{CV} \\
{[\%]}\end{array}$ & mean $\pm \mathrm{SD}$ & $\pm \mathrm{SE}$ & $\min$ & $\max$ & $\begin{array}{l}\mathrm{CV} \\
{[\%]}\end{array}$ & mean $\pm \mathrm{SD}$ & $\pm \mathrm{SE}$ & $\min$ & $\max$ & $\begin{array}{l}\mathrm{CV} \\
{[\%]}\end{array}$ \\
\hline 1987 & $9.0 \pm 1.92$ & \pm 0.19 & 5 & 16 & 21.3 & $24.5 \pm 3.70$ & \pm 0.37 & 15.0 & 33.5 & 15.1 & $4.5 \pm 1.38$ & \pm 0.14 & 3.0 & 15.0 & 25.0 \\
\hline 1991 & $8.5 \pm 1.77$ & \pm 0.18 & 5 & 14 & 20.8 & $25.0 \pm 4.97$ & \pm 0.50 & 9.5 & 40.5 & 23.0 & $5.0 \pm 1.17$ & \pm 0.12 & 2.5 & 8.0 & 23.4 \\
\hline 1997 & $9.0 \pm 3.24$ & \pm 0.32 & 4 & 26 & 36.0 & $21.0 \pm 4.10$ & \pm 0.40 & 13.0 & 32.5 & 3.5 & $5.0 \pm 1.75$ & \pm 0.17 & 3.0 & 6.0 & 16.6 \\
\hline 2012 & $7.5 \pm 2.42$ & \pm 0.24 & 4 & 16 & 32.3 & $25.0 \pm 4.41$ & \pm 0.44 & 15.5 & 34.5 & 17.6 & $4.5 \pm 1.07$ & \pm 0.11 & 3.0 & 9.0 & 21.4 \\
\hline
\end{tabular}

Explanation: $\mathrm{n}=100$ individuals 
Table 8. Changes in the stem hight $[\mathrm{cm}]$ of generative Senecio rivularis individuals in 1987-2012

\begin{tabular}{ccccccc}
\hline Year & $\mathrm{n}$ & $\mathrm{Mean} \pm \mathrm{SD}$ & $\pm \mathrm{SE}$ & Min & Max & $\mathrm{CV}[\%]$ \\
\hline 1987 & 300 & $73.0 \pm 18.4$ & \pm 1.06 & 15 & 122 & 25.0 \\
1991 & 236 & $72.5 \pm 12.0$ & \pm 0.78 & 39 & 111 & 16.0 \\
1997 & 279 & $64.0 \pm 13.5$ & \pm 0.81 & 27 & 119 & 21.1 \\
2002 & 244 & $76.0 \pm 18.4$ & \pm 1.18 & 36 & 130 & 24.4 \\
2007 & 300 & $63.0 \pm 13.3$ & \pm 0.77 & 29 & 110 & 21.0 \\
2012 & 262 & $81.0 \pm 13.4$ & \pm 0.83 & 52 & 124 & 5.7
\end{tabular}

Explanation: $\mathrm{n}$ - number of individuals
Table 9. Changes in the rosette diameter [cm] of generative Senecio rivularis individuals in 1987-2012

\begin{tabular}{rcrcrrc}
\hline Year & $\mathrm{n}$ & Mean \pm SD & \pm SE & Min & Max & CV [\%] \\
\hline 1987 & 300 & $29.0 \pm 8.3$ & \pm 0.48 & 12 & 52 & 28.5 \\
1991 & 236 & $24.5 \pm 5.1$ & \pm 0.33 & 13 & 44 & 20.1 \\
1997 & 279 & $17.5 \pm 4.4$ & \pm 0.26 & 9 & 34 & 25.0 \\
2002 & 244 & $24.0 \pm 6.8$ & \pm 0.43 & 7 & 53 & 48.3 \\
2007 & 300 & $21.0 \pm 5.6$ & \pm 0.32 & 10 & 43 & 26.0 \\
2012 & 262 & $24.5 \pm 5.5$ & \pm 0.34 & 10 & 40 & 22.5 \\
\hline
\end{tabular}

Explanation: $\mathrm{n}$ - number of individuals

Table 10. Changes in the inflorescence diameter [cm] of generative Senecio rivularis individuals in 1987-2012

\begin{tabular}{ccrcrrr}
\hline Year & \multicolumn{1}{c}{$\mathrm{n}$} & Mean \pm SD & \pm SE & Min & Max & CV [\%] \\
\hline 1987 & 300 & $8.5 \pm 2.9$ & 0.17 & 2 & 18 & 34.6 \\
1991 & 236 & $10.0 \pm 1.9$ & 0.12 & 6 & 16 & 19.3 \\
1997 & 279 & $7.5 \pm 2.0$ & 0.12 & 1.5 & 13 & 27.0 \\
2002 & nd & nd & nd & nd & nd & nd \\
2007 & 300 & $9.5 \pm 2.4$ & 0.14 & 4 & 18 & 26.9 \\
2012 & 262 & $10.5 \pm 2.3$ & 0.14 & 5 & 23 & 21.5 \\
\hline
\end{tabular}

Explanations: $\mathrm{n}$ - number of individuals, $\mathrm{nd}-$ no data

cluster increased, as illustrated by the spatial organisation within the largest cluster located in the centre of the area (Table 6). This was accompanied by a decrease in some biometric parameters of the vegetative and generative individuals (Tables 7-11, Figs. 7-8). In 1991-1997, the population abundance slightly decreased to 11867 individuals. The further increase in the population area after 1997, accompanied by a decline in the abundance noted in the later periods, caused 'thinning' of plant spatial distribution and another increase in the mean values of a majority of parameters of generative individuals. Vegetative individuals exhibited substantially lower diversity throughout the study period 1987-2012 (Table 7, Fig. 7). The differences between the individual periods were highly statistically significant for all the analysed characteristics: the number of leaves in the rosette of vegetative individuals (the Friedman test; $\mathrm{F}=17.45 ; P=0.0006)$; the length of the longest leaf

Table 11. Changes in the head number of generative Senecio rivularis individuals in 1987-2012

\begin{tabular}{rcrcccc}
\hline Year & $\mathrm{n}$ & Mean \pm SD & \pm SE & Min & Max & CV [\%] \\
\hline 1987 & 300 & $9.5 \pm 3.3$ & 0.19 & 3 & 19 & 34.3 \\
1991 & 236 & $14.5 \pm 5.5$ & 0.36 & 5 & 35 & 38.0 \\
1997 & 279 & $10.5 \pm 4.1$ & 0.25 & 1 & 27 & 40.0 \\
2002 & 244 & $11.0 \pm 4.8$ & 0.31 & 1 & 29 & 43.0 \\
2007 & 300 & $12.0 \pm 5.0$ & 0.29 & 4 & 31 & 41.3 \\
2012 & 262 & $12.0 \pm 3.9$ & 0.24 & 5 & 29 & 32.0 \\
\hline
\end{tabular}

Explanation: $\mathrm{n}$ - number of individuals

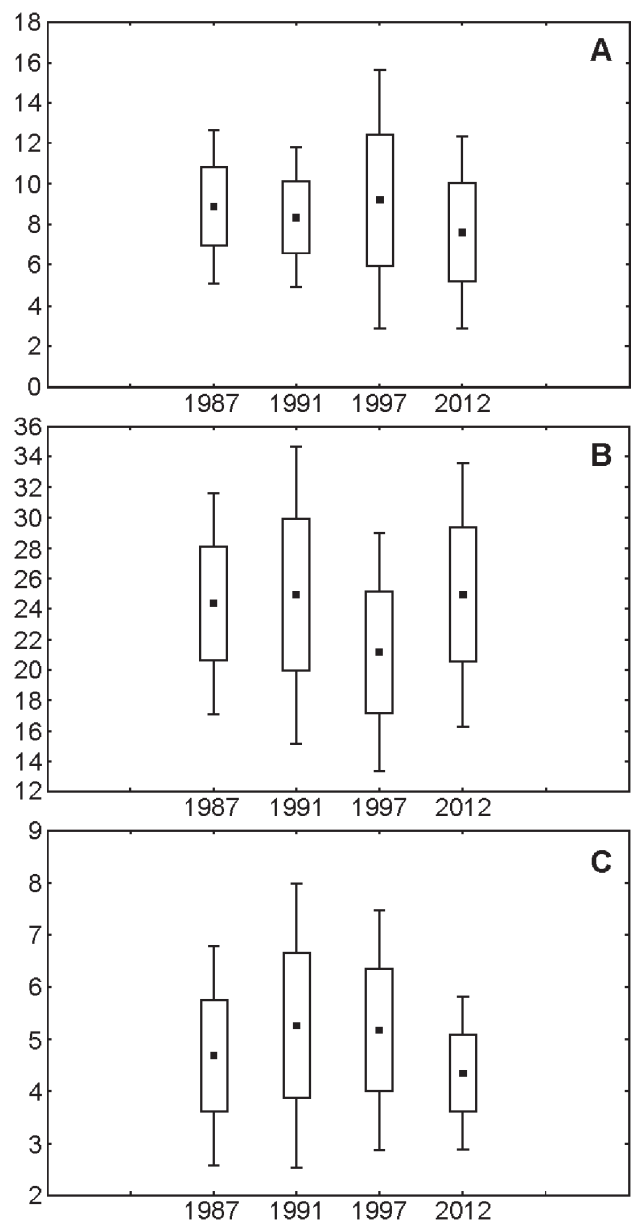

Fig. 7. Changes in parameters of vegetative individuals of Senecio rivularis in 1987-2012.

Explanations: $\mathrm{A}$ - number of leaves in a rosette, $\mathrm{B}$ - length of the longest leaf, $\mathrm{C}$ - width of the longest leaf, black points - mean value $(\overline{\mathrm{x}})$, boxes standard deviation (SD), whiskers - mean $\pm 1.96 \mathrm{SD}$ 

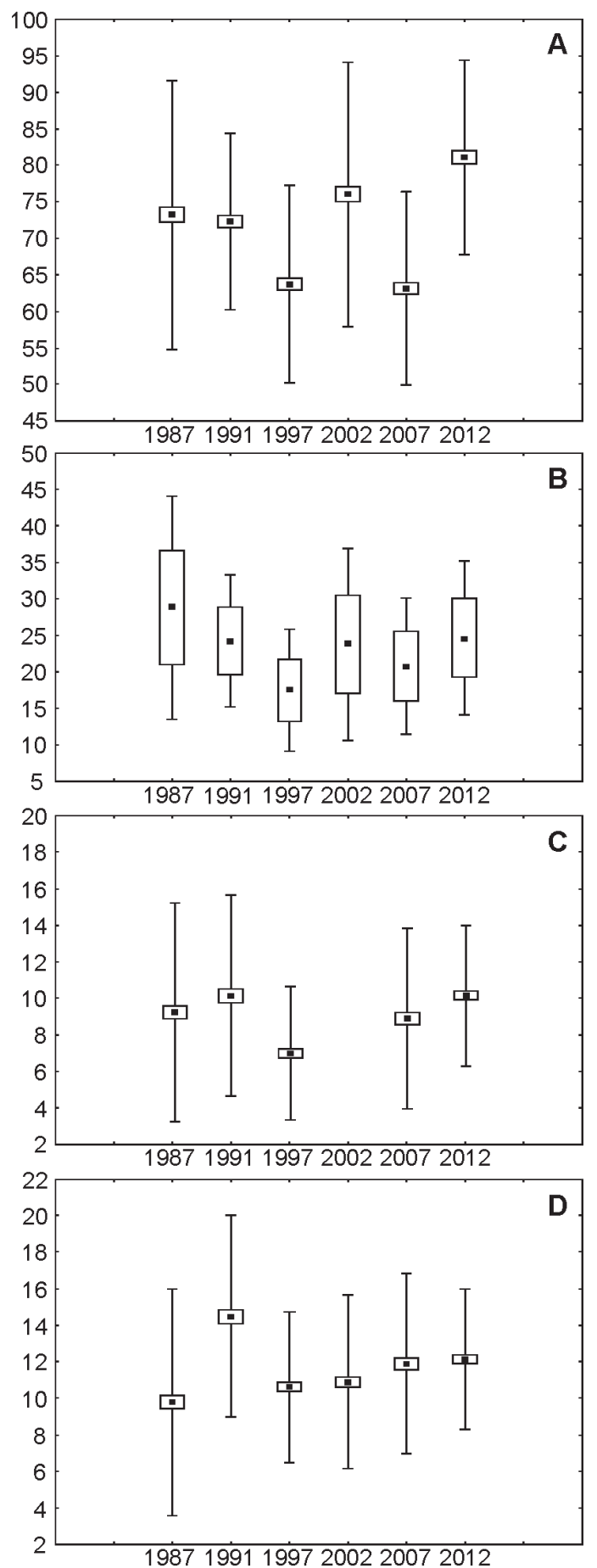

198719911997200220072012

Fig. 8. Changes in parameters of generative individuals of Senecio rivularis in 1987-2012

Explanations: A - stem height (in $\mathrm{cm}$ ), B - rosette diameter (in $\mathrm{cm}$ ), C inflorescence diameter (in cm), D - number of heads. For A, C and D: black points - mean value $(\overline{\mathrm{x}})$, boxes - standard error $(\mathrm{SE})$, whiskers - standard deviation (SD), for B: whiskers - mean $\pm 1.96 \mathrm{SD}$

(Levene's test; $\mathrm{L}=18.49 ; P=0.0001)$; the width of the longest leaf $(\mathrm{F}=27.00 ; P=0.0000)$; the stem height of generative individuals $(\mathrm{F}=198.66 ; P=0.0000)$; the leaf rosette diameter $(\mathrm{F}=323.98 ; P=0.0001)$; the inflorescence diameter $(\mathrm{F}=192.99 ; P=0.0000)$; and the number of flower heads in the inflorescence $(\mathrm{F}=1621.00$; $P=0.0001)$.

\section{Discussion}

\subsection{Width of a species habitat niche at the limits of} the geographic range

Besides the phenology, life form, and regenerative ability, the habitat niche is among the main components of a plant niche defined as a range of physico-chemical and climatic conditions promoting plant development (Grubb 1977).

Usually the geographic distribution of species abundance is heterogeneous, i.e., populations are most abundant at the centre of the species range and become least abundant at the margins of the range (Hengeveld \& Haeck 1982). Numerous factors have been proposed, in isolation or in combination, to limit geographic ranges of species (Gaston 2009). When moving from the centre to the margins, the habitat niche shrinks and the population density decreases (Gaston \& Lawton 1990; Gaston 1991; Novotny 1991). Additionally, climatic conditions may limit the supply of viable and fertile seeds or delay phenological phenomena, including seed germination, and increase mortality of seedlings, thereby reducing the chance of natural regeneration, which was shown for some tree species (e.g. Pigott \& Huntley 1981; Holm 1993). Abies alba, which extends to the north-eastern border of its geographic range in Poland declined in abundance in all geographic regions (including mountain, highland and lowland populations) and in all types of plant communities, even in an associations optimal to this species, i.e., in primeval mountain forests without a direct human impact (e.g. Jaworski \& Kaczmarski 1990) and upland mixed fir forest (Mazur 1989; Maciejewski 1998; Tracz 2014). Factors responsible for this process can be divided into three groups: abiotic, biotic, and anthropogenic ones, all of which hamper the natural regeneration of the species and cause the dying of trees (Sierpiński 1977), but this issue was not the aim of this study.

A majority of previous studies on silver fir focused on habitat preferences and dynamics of the species in forest communities with high abundance of this tree species, particularly beech forests and spruce-fir forests that occurred in the lower forest belt in the mountains and in mixed fir forests and the Carpathian beechwood in highlands (e.g., Matuszkiewicz J. 1977; Wojterski 1983; Mazur 1989; Izdebski et al. 1992; Maciejewski 1998). During the present studies in two areas of the central part of the Roztocze Highlands, SE Poland, where silver fir reaches the limits of its massive occurrence, the species was found to be a significant admixture in a broader range of plant communities: pine forests, mixed coniferous forests, lime-hornbeam forest, maple-lime forest, xero-thermophilous oak forest, ash-alder forest, and bog alder forest; the two latter types more frequently in river gorge section areas of the SW escarpment zone of the region. 
A. alba can grow on different relief forms (Matuszkiewicz J. 1977, 2001; Jaworski \& Zarzycki 1983). Forests with the highest cover of fir (mainly mixed fir forests) are present in opposite conditions in the two study areas. In the RNP, with an area being an example of a landscape of high Cretaceous or rarely Neogene hills of the Roztocze Highlands (Buraczyński 2002), fir forests are mainly present in plain or slightly hilly areas. In turn, in the landscape of the river valleys, they overgrow steep slopes of river gorge sections, giving them a mountainous character. The participation of fir increases along with the increase in the incision of the valleys into the bedrock as well as with the increase in the steepness of slopes. The gorge sections of the rivers: Jeleń, Szum and Sopot, where the incision of the valleys reaches the values between 15 and $27 \mathrm{~m}$ and the steepness is $40-50^{\circ}$, the slopes are almost exclusively dominated by fir tree stands (Czarnecka \& Janiec 2002, 2006).

Silver fir tolerates a wide range of edaphic conditions in respect of soil moisture, acidity, organic matter content, nutrient availability, and granulometric composition and grows on different soil types (Matuszkiewicz J. 1977; Jaworski \& Zarzycki 1983; Zarzycki et al. 2002). In the RV sites, it seems to have much broader ecological amplitude in terms of not only forest communities but also soil types than in the RNP area. As for its ecological requirements, $A$. alba is usually placed between beech Fagus sylvatica L. and spruce Picea abies (L.) H. Karst. (Jaworski \& Zarzycki 1983). In the Roztocze Highlands, especially in the landscape of river valleys, silver fir occupies habitats that are too leachy for deciduous species and even for spruce. While deciduous species encroachment into the habitats of mixed fir forests is observed in the RNP area (Izdebski et al. 1992; Maciejewski 1998), there is no competition from such species on the steep slopes of the river valleys; apart from the valleys of the Szum and Potok Łosiniecki rivers, beech and hornbeam Carpinus betulus L. are virtually absent (Czarnecka \& Janiec 2002). In turn, fir often enters habitats with semihydrogenic or even hydrogenic soils on the bottoms of the valleys inhabited by ash-alder and bog alder forests. It seems that at the limits of its geographic range, the species extends its habitat niche.

\subsection{Dynamics of an individual size structure in a marginal population}

The size structure of an individual is commonly considered one of the most important plant traits determining the role of an individual in a population, contributing to reproduction, and, in consequence, to the population dynamics (Harper 1977; Stearns 1992; Silvertown \& Lovett-Doust 1993; Hutchings 1997; Begon et al. 2008).
The size structure is affected both by species features and by habitat conditions, and it may change simultaneously with other changes in the population of a given species and in the populations of co-existing species (Weiner \& Solbrig 1984; Hara 1988; Weiner 1995). The size structure of Senecio rivularis individuals is usually far from being uniform and stabile, which is indicated by the scatter of the minimum and maximum values, as well as the coefficient of variation and highly significant differences in all studied features during the whole study period. Generally, the highest CV value was exhibited by the leaf rosette diameter and the number of flower heads in the inflorescence. Among the biotic intercorrelations, competition for environmental resources is indicated as a factor that leads to the structuring of plant size in respect of vegetative and generative traits. The competitive ability varies as a function of plant age or life-stage and is often categorized as size-symmetric at equal interactions between neighbouring individuals or size-asymmetric, when the larger competitor suppresses the growth of a smaller plant, but the smaller one has no adverse effect on the larger, which increases the inequality of a plant population over time (White \& Harper 1970; Grubb 1977; Weiner 1990; Silvertown \& Lovett Doust 1993; Hara \& Wyszomirski 1994; Law et al. 1997; Schwinning \& Weiner 1998; Freckleton \& Watkinson 2001; Lamb \& Cahill 2006). Asymmetry is an essential part of the mechanism by which competition generates size hierarchy in plant population (Firbank \& Watkinson 1987; Howard \& Goldberg 2001). The intrapopulation diversity of the individuals' size implies varied chance for survival and production of offspring ('bigger means stronger'), and determines the future genetic structure.

The size structure of individuals is a density-dependent trait of a population (White \& Harper 1970; Weiner 1990; Silvertown \& Lovett Doust 1993; Gersani et al. 1998; Weiner et al. 2001). The size of the particular plant is a function of the 'available area' and resources available therein - space, light, water, and nutrients (Mithen et al. 1984). Together with the depletion of habitat resources, the competition between genets becomes stronger, generating 'self-thinning' within a given clump. In the first period of the observation (1987-1997), the intrapopulation relationships became more and more important, together with the increase in the density of $S$. rivularis genets within individual patches and with the changes in the stage structure of the genets - from the dominance of juvenile genets and/ or unitary mature genets to the dominance of mature genets of iterative growth (Czarnecka 2008). This was reflected in the decrease in the mean values of a majority of the analysed traits, especially in the generative individuals. The parameters of the individuals increased again in 2002-2012, which was associated with, e.g., 
appearance of a new generation after local or periodical waterlogging caused by the rising groundwater level at the end of the 90s, which resulted in extinction of individuals in a part of the population area (Czarnecka 2008; B. Czarnecka, unpbl. data).

Another cause of the 'thinning' of the population was the gradual expansion of the population onto sunny or slightly shady sites appearing at the gaps in the tree stand, due to overturning of pine trees. This was observed both at the edges of the area (enlargement of the area) and inside the area (filling the area). If such microhabitats were additionally characterised by other favourable conditions for S. rivularis, e.g. small, slightly wet ground depressions filled with organic formations with pH 5.5-6.5 (Czarnecka 1995), they were inhabited by new cohorts of individuals of this species, which reached the generative stage in the $4^{\text {th }}-5^{\text {th }}$ growing season. The decrease in the coefficient of variation of the parameters of generative individuals in the final study season implies unification of the structure size and, hence, the living conditions in the entire population area. Genets located in new, peripheral clumps are characterised by a higher biotic potential expressed in, e.g., a greater number of reproductive episodes and diaspore production during life-span and greater reproductive success (higher percentage of plants reaching the reproductive phase) in comparison with those inhabiting the 'primary' part of the population area with probably depleted habitat resources (Czarnecka 1995, 2006). This confirmed earlier suggestions that a given population may be divided into small-scale patches with their own dynamics (e.g. Silvertown \& Wilkin 1983; Rusch 1992). All these statements seem to be justified because they were drawn on the basis of 25-year research, during which the size structure individuals was investigated several times within the whole marginal population. Simple statistical measurements performed over a longtime period provide valuable information about the role of an individual in a changing population.

\section{Conclusions: Living on the edge - advantages and drawbacks}

1. Living on the edge means that the habitat conditions are far from optimal, and species have to fit to the variable and changing environmental conditions (= 'evolution on the run').

2. Species have to expand their original habitat niche and/or search for an alternative niche, thereby contributing to greater diversity in the occupied habitats.

3. At the edge of geographic range often insular (usually smaller) populations occur.

4. Within small insular populations, there is an autonomy of patches, which ensures reproduction in case of the occurrence of adverse conditions in a vegetation season.

5. Within marginal populations, the abundance might decline rapidly, which might lead to genetic drift.

Acknowledgements. I would like to thank my former biology students: Bożena Sadurska, Dorota Jankowska, Agnieszka Ziółkowska, Katarzyna Fita, Urszula Kaczorowska, Joanna Gilas, Elżbieta Krzysztyniak, Monika Władyka, Paulina Dróżdż, as well as former and present co-workers: Krystyna Kowalska, MSc., Anna Majewska, MSc., Paweł Dzirba, MSc., Aneta Ptaszyńska, PhD., Arkadiusz Banaś, MSc., Joanna Czarnecka, PhD., and Zbigniew Cierech, PhD. for their kind assistance in the field work and help with statistics and preparation of the figures.

\section{References}

Bajkiewicz-Grabowska E. \& Mikulski Z. 1999. Hydrologia ogólna. 298 pp. Wyd. Nauk. PWN, Warszawa.

Begon M., Towsend C. R. \& Harper J. L. 2008. Ecology: From individuals to ecosystems. 4th edn. 738 pp. Blackwell Publ., Oxford.

BuRACZYŃSKi J. 2002 (ed.). Roztocze. Środowisko przyrodnicze. 341 pp. UMCS, Lublin.

Czarnecka B. 1995. Biologia i ekologia izolowanych populacji Senecio rivularis (Waldst. et Kit.) DC. i Senecio umbrosus Waldst. et Kit. 263 pp. Wyd. UMCS, Lublin.

CZARneCKA B. 2006. The status of individuals within a changing plant population and community: the example of Senecio rivularis (Asteraceae). Pol. Bot. Stud. 22: 155-164.
Czarnecka B. 2008. Spatiotemporal patterns of genets and ramets in a population of clonal perennial Senecio rivularis: plant features and habitat effects. Ann. Bot. Fenn. 45: 19-32.

Czarnecka B. 2010. Górskie gatunki roślin naczyniowych na Roztoczu: kilka uwag o rozmieszczeniu i ekologii. In: J. R. RAK (ed.). Walory ekologiczne i turystyczne północnej części Euroregionu Karpackiego, pp. 89121. Wyd. Muz. Reg. im. A. Fastnachta w Brzozowie, Brzozów.

Czarnecka B. 2011. Formation and dynamics of the metapopulation of Senecio rivularis (Waldst. \& Kit.) DC. on the limits of its geographic range: where, when, by what means? Pol. J. Ecol. 59: 263-278. 
Czarnecka B. \& Janiec B. 2002. Przełomy rzeczne Roztocza jako modelowe obiekty w edukacji ekologicznej. 232 pp. Wyd. UMCS, Lublin.

CzarnecKa B. \& JANIEC B. 2006. Krajobrazy roślinne jako wyraz naturalnych i antropogenicznych przemian środowiska małych dolin rzecznych Roztocza. Probl. Ekol. Kraj. 16: 185-195.

Dobrzański B., Uziak S., Klimowicz Z. \& Melke J. 1992. Badania gleb w laboratorium i w polu. 331 pp. UMCS, Wydz. Biologii i Nauk o Ziemi, Lublin.

EuropeAn COMmISSION 2007. Interpretation manual of European Union habitats. Eur 27. DG Environment.

FALIŃSKi J. B. 2001. Przewodnik do długoterminowych badań ekologicznych. In: J. B. FALiŃski (ed.). Vademecum Geobotanicum 1, 672 pp. Wyd. Nauk. PWN, Warszawa.

Firbank L. G. \& WatKInSON A. R. 1987. On the analysis of competition at the level of the individual plant. Oecologia 71: 308-317.

Freckleton R. P. \& Watkinson A. R. 2001. Asymmetric competition between plant species. Funct. Ecol. 15: 615-623.

Gaston K. J. 1991. How large is a species' geographic range? Oikos 61: 434-437. http://dx.doi.org/10.2307/3545251

Gaston K. J. 2009. Geographic range limits of species. Proc. R. Soc. B 276: 1391-1393.

Gaston K. J. \& LAwTON J. H. 1990. Effects of scale and habitat on the relationship between regional distribution and local abundance. Oikos 58: 329-335.

Gersani M., Abramsky Z. \& Falik O. 1998. Densitydependent habitat selection in plants. Evolut. Ecol. 12: 223-234.

GRUBB P. J. 1977. The maintenance of species-richness in plant communities: the importance of the regenerative niche. Biol. Rev. 52: 107-145.

Hengeveld R. \& Haeck J. 1982. The distribution of abundance. I. Measurements. J. Biogeogr. 9: 303-316.

HARA T. 1988. Dynamics of size structure in plant populations. Trend Ecol. Evol. 3: 129-133. http://dx.doi. org/10.1016/0169-5347(88)90175-9

Hara T. \& Wyszomirski T. 1994. Competitive asymmetry reduces spatial effects on size-structure dynamics in plant populations. Ann. Bot. 73: 285-297.

Harper J. L. 1977. Population biology of plants. 892 pp. Acad. Press, London.

Holm S. O. 1993. Regeneration of Betula pendula and B. pubescens coll. above and below the natural altitudinal distribution limit of $B$. pendula in south-east Norway. Oecol. Mont. 2: 1-6.

Howard T. G. \& GoldBerg D. E. 2001. Competitive response hierarchies for germination, growth, and survival and their influence on abundance. Ecology 82: 979-990.

Hutchings M.J. 1997: The structure of plant populations. In: M. J. Crawley (ed.). Plant ecology, pp. 325-358. Blackwell Sci., Oxford.

Izdebski K., Czarnecka B., Grądziel T., Lorens B. \& PopioŁeK Z. 1992. Zbiorowiska roślinne Roztoczańskiego Parku Narodowego na tle warunków siedliskowych. 268 pp. Wyd. UMCS, Lublin.

JAWORSKi A. \& KACZMARSKI J. 1990. Struktura i dynamika dolnoreglowych drzewostanów o charakterze pier- wotnym w Babiogórskim Parku Narodowym (na przykładzie trzech powierzchni doświadczalnych). Acta Agr. Silv., ser. Silv. 29: 31-48.

JAWORSKi A. \& ZARZYCKi K. 1983. Ekologia. In: S. BiAŁoboK (ed.). Jodła pospolita Abies alba Mill. Nasze drzewa leśne, T. 4, pp. 317-430. PWN, Warszawa-Poznań.

KucharczyK M. 2000. Ginące i zagrożone gatunki roślin naczyniowych województwa lubelskiego. Lub. Urząd Woj., Lublin (mscr.).

Lamb E. G. \& Cahill J. F. 2006. Consequences of differing competitive abilities between juvenile and adult plants. Oikos 112: 502-512.

Law R., Marrow P. \& Dieckmann U. 1997. On evolution under asymmetric competition. Evol. Ecol. 11: 485-501.

ŁOMNICKI A. 2007. Wprowadzenie do statystyki dla przyrodników. 282 pp. Wyd. Nauk. PWN, Warszawa.

MACIEJEWSKI Z. 1998. Long-term changes in the abundance and mass of the main tree species in beechwood and fir forest communities of Roztoczański National Park (east-central Poland). Pol. J. Ecol. 46: 169-186.

Matuszkiewicz J. 1977. Przegląd fitosocjologiczny zbiorowisk leśnych Polski. Cz. 4. Bory świerkowe i jodłowe. Phytocoenosis 6: 151-227.

Matuszkiewicz J. M. 2001. Zespoły leśne Polski. 358 pp. Wyd. Nauk. PWN, Warszawa.

MatuszKiewicz W. 2008. Przewodnik do oznaczania zbiorowisk roślinnych Polski. In: J. B. FALIŃSKi (ed.). Vademecum Geobotanicum 3, 537 pp. Wyd. Nauk. PWN, Warszawa.

Mazur M. 1989. Structure and dynamics of silver fir (Abies alba Mill.) population in forest communities of the Świętokrzyski National Park. II. Population dynamics. Acta Soc. Bot. Pol. 58: 409-422.

Meusel H. \& JäGer E. J. (Hrsg.). 1992. Vergleichende Chorologie der zentraleuropäischen Flora. III. Text $i x+333$ pp., Karten, Literatur, Register pp. ix+422688. Gustav Fischer Verlag, Jena-Stuttgart-New York.

Mirek Z., PięKoś-Mirkowa H., Zając A. \& Zając M. 2002. Flowering plants and pteridophytes of Poland. A checklist. In: Z. MireK (ed.). Biodiversity of Poland, 1, 442 pp. W. Szafer Institute of Botany, Polish Academy of Sciences, Kraków.

Mithen R., HARPer J. L. \& Weiner J. 1984. Growth and mortality of individual plants as a function of "available area". Oecologia 62: 57-60.

Novotny V. 1991. Effect of habitat persistence on the relationship between geographic distribution and local abundance. Oikos 6: 431-433.

PAWŁowsKA S. 1972. Charakterystyka statystyczna i elementy flory polskiej. In: W. SZAFER \& K. ZARZYCKI (eds.). Szata roślinna Polski. T. I, pp. 129-206. PWN, Warszawa.

Pigott C. D. \& Huntley J. P. 1981. Factors controlling the distribution of Tilia cordata at the northern limits of its geographic range. III. Nature and causes of seed sterility. New. Phytol. 87: 817-839.

Rusch G. 1992. Spatial pattern of seedling recruitment at two different scales in a limestone grassland. Oikos 65: 433-442.

SAPEK A. \& SAPEK B. 1992. Metody analizy chemicznej gleb organicznych. 80 pp. Wyd. IMUZ, Falenty. 
SChwinning S. \& WeIner J. 1998. Mechanisms determining the degree of size asymmetry in competition among plants. Oecologia 113: 447-455.

SieRPIŃSKi Z. 1977. Przyczyny zamierania jodły w Górach Świętokrzyskich. Sylwan 11: 29-42.

Silvertown J. W. \& Lovett Doust J. 1993. Introduction to plant population biology. 3rd edn. 208 pp. Blackwell Sci., Oxford.

Silvertown J. W. \& Wilkin F. R. 1983. An experimental test of the role of micro-spatial heterogeneity in the co-existence of congeneric plants. Bot. J. Linn. Soc. 19: 1-18.

STANISZ A. 1998. Przystępny kurs statystyki w oparciu o program "STATISTICA PL" na przykładach z medycyny. 362 pp. Wyd. StatSoft Polska.

Stearns S. C. 1992. The evolution of life histories. 249 pp. Oxford Univ. Press, Oxford.

StEINHAus H. 1947. O wskaźniku zagęszczenia i rozproszenia. Przegląd Geogr. 21: 1-3.

SzAFER W. 1930. Element górski we florze niżu polskiego. Rozpr. Wydz. Mat.-Przyr., PAU, s. 3, dz. B 69: 83-196.

Tracz J. 2014. Tendencje zmian borów jodłowych na Roztocza Środkowym i Południowym. Ph. D. Thesis, Zakł. Geobot. UMCS, Lublin.

TrzciŃSKi W. (ed.). 1989. Systematyka gleb Polski. Roczn. Gleb. 40: 1-62.

WeINER J. 1990. Asymmetric competition in plant populations. Trends Ecol. Evol. 5: 360-364. http://dx.doi. org/10.1016/0169-5347(90)90095-U
WeIner J. 1995. Following the growth of individuals in crowded plant populations. Trends Ecol. Evol. 10: 389-390.

Weiner J. \& Solbrig O. T. 1984. The meaning and measurement of size hierarchies in plant populations. Oecologia 61: 334-336.

Weiner J., Stoll P., Muller-Landau H. \& Jasentuliyana A. 2001. The effects of density, spatial pattern, and competitive symmetry on size variation in simulated plant populations. Am. Nat. 158: 438-450.

White J. \& Harper J. L. 1970. Correlated changes in plant size and number in plant populations. J. Ecol. 58: 467-485.

Wojterski T. 1983. Lasy z udziałem jodły w Polsce. In: S. Bıаєовок (ed.). Jodła pospolita Abies alba Mill. Nasze drzewa leśne, T. 4, pp. 431-481. PWN, WarszawaPoznań.

ZAJĄC M. 1996. Mountain vascular plants in the Polish Lowlands. Pol. Bot. Stud. 11: 1- 92.

ZAJĄC A. \& ZAJĄC M. (eds.). 2001. Distribution Atlas of Vascular Plants in Poland. xii+714 pp. Edited by Laboratory of Computer Chorology, Institute of Botany, Jagiellonian University, Cracow.

Zarzycki K., TrZcińsKa-TaciK H., RóżAŃSKi W., Szeląg Z., WoleK J. \& KorzeniaK U. 2002. Ecological indicator values of vascular plants of Poland. In: Z. MireK (ed.). Biodiversity of Poland, 2, 183 pp. W. Szafer Institute of Botany, Polish Academy of Sciences, Kraków. 